\title{
Analysis of incidence and overall survival of patients with vulvar cancer in Poland in 2008-2016 - implications for cancer registries
}

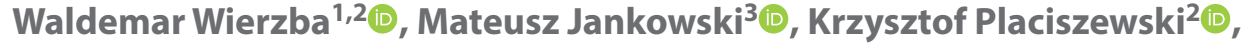

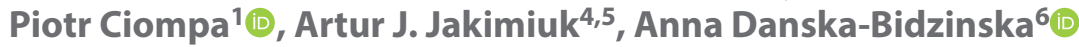 \\ ${ }^{1}$ University of Humanities and Economics in Lodz, Poland \\ ${ }^{2}$ Central Clinical Hospital of the Ministry of Internal Affairs and Administration, Warsaw, Poland \\ ${ }^{3}$ School of Public Health, Centre of Postgraduate Medical Education, Warsaw, Poland \\ ${ }^{4}$ Department of Obstetrics and Gynecology, Central Clinical Hospital of Interior Affairs and Administration, Warsaw, Poland \\ ${ }^{5}$ Center of Reproductive Health, Institute of Mother and Child, Warsaw, Poland \\ ${ }^{6}$ Chair and Department of Obstetrics, Gynaecology and Oncology, $2^{\text {nd }}$ Faculty of Medicine, Medical University of Warsaw, Poland
}

\begin{abstract}
Objectives: To analyze the incidence and overall survival rate of patients with vulvar cancer in Poland, based on the reporting data from the National Health Fund.

Material and methods: The incidence of vulvar cancer in Poland in 2008-2016 (9-year follow-up period) by voivodship and the number of patients undergoing combined hospital treatment were analyzed. For the group of patients treated systemically, overall survival (OS) probability was calculated using the Kaplan-Meier estimation method.

Results: In the period 2008-2016 in Poland, the diagnosis of malignant neoplasm of the vulva (C51\% group) was made in 29,702 patients. The mean annual prevalence rate per 100,000 inhabitants was $8.3 \pm 1.2$ for Poland. The largest numbers of patients were reported in Mazowieckie and Slaskie voivodeships and the lowest in Opolskie and Podlaskie voivodeships. The median overall survival of patients treated with the combined method in 2008-2016 in Poland was 64.7 months (95\% Cl: $58.0-70.0$ ). One-year survival rate was observed in $77.6 \%$ of patients, 2 -year in $64.4 \%$, 3-year in $58 \%$, over 5 years $-54.22 \%$.

Conclusions: In the years 2008-2016 in Poland, based on the data reported to the National Health Fund, the incidence of vulvar cancer was 4 times higher than the statistics of the National Cancer Registry, the WHO or the USA, which indicates either substantive or reporting errors. In Poland, $54 \%$ of patients treated with the combined therapy survive over 5 years which is a much lower result compared to highly developed countries.
\end{abstract}

Key word: vulvar cancer; overall survival; combined therapy; retrospective analysis; Poland

Ginekologia Polska 2022; 93, 6: 460-466

\section{INTRODUCTION}

Malignant neoplasms of the vulva occur most often after the age of 60 [1] and by some are classified as diseases of the menopausal age. Observations in recent years indicate an increase in the incidence amongst younger patients [2]. Malignant neoplasm of the vulva is a rare neoplasm, it accounts for only $2-5 \%$ of all malignant neoplasms of female genital organs [2]. However, in the last decade, an increase in new cases was observed from about $0.6 \%$ each year, which resulted in an increase in mortality due to this cancer by an average of about $1.2 \%$ in the period between 2005 and 2014 [4]. Malignant neoplasms of the vulva jointly with malignant neoplasms of the vagina, account for only one percent of all malignant neoplasms in women in Poland. Similarly, malignant neoplasms of the vulva and vagina are responsible for one percent of cancer deaths in women in Poland [3, 4]. According to the studies of the National Cancer Registry (NCR), in patients diagnosed with malignant neoplasm of the vulva and vagina (NCR studies those tumours jointly), the one-year survival rate in 2000-2002 was

\footnotetext{
Corresponding author:

Mateusz Jankowski

School of Public Health, Centre of Postgraduate Medical Education, Warsaw, Poland

e-mail: mateusz.jankowski@cmkp.edu.pl
} 
$71.2 \%$ and in $2003-2005$ it was $69.4 \%$. The five-year survival rates in the group of patients with vulvar and vaginal cancer in the years $2000-2002$ accounted for $51.8 \%$ and in the years 2003-2005 for $48.6 \%$ of patients, respectively [4].

In the Polish literature, there are practically no in-depth data on the prevalence and overall survival rate of patients diagnosed with vulvar malignant neoplasm. Even the data of the Polish National Cancer Registry combine this information with the data on malignant tumours of vagina. Therefore, the aim of this study was to analyze the incidence and overall survival rate of patients with vulvar cancer in Poland, based on the reporting data from the National Health Fund.

\section{MATERIAL AND METHODS}

From the reporting database of the National Health Fund, the only public payer in Poland, the data of patients were collected for analysis from 2008-2016, who were shown to the payer with the diagnosis from C51\% group - vulvar malignant neoplasm, according to ICD-10 [5]. The PESEL number (personal identification number) [6] was recognized as the unique identifier of the patient. Then, from those data, further information was extracted on patient hospital treatment. The analysis included data in which there was a simultaneous occurrence of the unique individual patient number (PESEL number) and diagnosis from the selected group. Then, a subset was created in the database in order to distinguish the data of patients undergoing combined treatment (chemotherapy, radio[chemo]therapy, surgery). Overall survival was analyzed in this group. The analysis covered the data of patients treated in the period from $1^{\text {st }}$ January 2008 to $31^{\text {st }}$ December 2016. The start date was the first date of the treatment given; the observation cut-off date was set on $31^{\text {st }}$ December 2016. The number of neoplasms diagnosed according to the ICD-10 classification reported to the NHF was analyzed [5] in given types of services (health care subsegments) [7]. The number of diagnoses was analyzed by voivodship (reporting to NHF regional departments) in the nine-year period, separately for each year. In addition, for the group of patients undergoing combined therapy within hospital treatment (subsegment 03 - Hospital Treatment) $12,24,36$ and 60-month survival rates were calculated using the Kaplan-Meier estimator. The median follow-up time was calculated based on the censored observation time (the median follow-up time value represents the time during which $50 \%$ of living patients were observed until the end of the analysis, i.e., until $31^{\text {st }}$ December 2016). Data on the date of patient death was obtained based on the PESEL database from the Home Office. Overall survival analysis was performed with the Kaplan-Meier estimator and use of survival tables [8]. The results were developed in SAS Enterprise software Guide 7.1.

\section{RESULTS}

In Poland, there are 17 types of health services otherwise referred to as health care subsegments [7]. In the period 2008-2016 in Poland, the diagnosis of malignant neoplasm of vulva (C51\% group) was made in 29,702 patients, on average annual approximately 3,300 patients per year. The percentage distribution of those patients among individual health care segments in Poland is presented in Table 1. The largest number of patients diagnosed in the analyzed group occurred in the Outpatient Specialist (Secondary) Care (ambulatory specialized services - 45\%); then in primary care (general practitioners - 21\%) and in hospital treatment care (17.3\%).

The number of patients diagnosed with $\mathrm{C} 51 \%$ in individual voivodeships directly correlates with the size of the voivodeship and frequency of highly specialized centres (Tab. 2). The largest numbers of patients were reported in the following voivodships: Mazowieckie (average annual about 500 people); Slaskie (approx. 490 people average annual) as well as in Wielkopolskie and Dolnoslaskie (approx. 280 people on average annual).

The lowest number of patients was reported in the following voivodships: Opolskie (about 70 people on average annual) and Podlaskie (approx. 90 people on average annual) as well as Swietokrzyskie and Podkarpackie (approx. 120 people on average annual). Mean annual prevalence rate per 100,000 inhabitants was $8.28 \pm 1.23$ for Poland.

The mean age of the patient with malignant neoplasm of vulva (C51\% diagnosis) at the time of providing with healthcare services increased with the year of observation (Tab. 3)

On average, $24 \%$ of patients from a cohort of patients diagnosed with malignant neoplasm of vulva (C51\% diagnosis) received treatment as part of inpatient therapy. The number of these patients by voivodship is presented in Table 4.

The highest percentage of people receiving hospital treatment was observed in the following voivodships: Mazowieckie (56.2\%), Slaskie (51.8\%), Malopolskie (35.2\%); the lowest percentage is in the following voivodeships: Lubuskie (6.87\%), Opolskie (7.2\%), Warminsko-Mazurskie (9.7\%).

Overall survival was based on a cohort of patients undergoing combination therapy as part of hospital treatment (Fig. 1). The median overall survival in the analyzed cohort of patients (4319 people) in the years 2008-2016 (9years) was 64.7 months (95\% Cl: 58.0-70.0). 1783 were full observations and 2536 (58.72\%) were censored. one-year (12 months) survival occurred in $77.6 \%$ of patients, two-year ( 24 months) in $64.4 \%$, three-year (36 months) in 58.43 (months), over five years (60 months) $-54.22 \%$. 
Table 1. Distribution of patients with malignant neoplasm of vulva (C51\% diagnosis) between types of health services in Poland (healthcare subsegments) in the years 2008-2016

\begin{tabular}{|l|c|}
\hline Type of healthcare service according to the National Health Fund classification & $\begin{array}{c}\text { Percentage of patients receiving } \\
\text { the healthcare service }\end{array}$ \\
\hline 1. Primary care & $21 \%$ \\
\hline 2. Ambulatory specialized services & $45 \%$ \\
\hline 3. Hospital treatment & $17.3 \%$ \\
\hline 4. Psychiatric care and treatment of addictions & $0.0 \%$ \\
\hline 5. Medical rehabilitation & $1.2 \%$ \\
\hline 6. Long-term care & $5.9 \%$ \\
\hline 7. Dental treatment & $0.0 \%$ \\
\hline 8. Sanatorium treatment & $0.0 \%$ \\
\hline 9. Emergency assistance and sanitary transport & $0.0 \%$ \\
\hline 10. Preventive health programs & $6.4 \%$ \\
\hline 11. Separately contracted services & $0.8 \%$ \\
\hline 12. Supplied of orthopedic equipment, auxiliaries and medical technical measures & $0.0 \%$ \\
\hline 13. Drug price reimbursement & $0.0 \%$ \\
\hline 14. Nursing and care services & $1.0 \%$ \\
\hline 15. Palliative and hospice care & $1.4 \%$ \\
\hline 16. Emergency Medical services & $0.0 \%$ \\
\hline 17. Emergency assistance and sanitary transport from 2009 & $0.0 \%$ \\
\hline
\end{tabular}

\section{DISCUSSION}

Cancer of vulva makes $2-5 \%$ of all malignant neoplasms of the female genital organs and one percent of all malignancies in women. The incidence rate ranges from $0.1-2.6$ per 100,000 in various populations and regions of the world. The world average is 1.2 [1-4].

In Poland, vulvar cancer ranks fourth in terms of the incidence of malignant neoplasms of the reproductive organs: after cervical, ovarian and endometrial cancer. There are approximately 350 new cases of this cancer diagnosed in Poland every year. Every year 200 women die from vulvar cancer in Poland (National Cancer Registry data). The average (raw) incidence rate in our country is 1.4 per 100,000 [4]. According to the data reported to the National Health Fund, this ratio is 8.3 per 100,000 , which may indicate over-diagnosing or errors in reporting. The mean age at diagnosis is 69 years. In the group of patients diagnosed with vulvar cancer, only one in four (24\%) was qualified for systemic treatment. There is a significant difference in the number of patients undergoing combined inpatient treatment between the voivodships: Mazowieckie 56\%, Slaskie 51\% vs. Lubuskie 6.8\%, Warmińsko-Mazurskie 9.7\%. These data indicate organizational problems (distance from reference medical centres), insufficient specialist knowledge amongst medical personnel, difficulties with access to highly specialized services, but also probably low patient health awareness in the age group over 60 and their health condition related to multiple co-morbidities disqualifying them from combined therapy. The consequence of the above-mentioned problems is the result of only $54 \%$ of five-year survival in the group of patients treated with combined therapy.

For comparison, according to data from the United States, $0.3 \%$ of the female population is at risk of being diagnosed with vulvar cancer. Every year, there are 6,070 new cases (2.2 per 100,000$)$ and 1,280 deaths ( 0.5 per 100,000$)$, $71.1 \%$ will survive five years - these data have remained unchanged for 40 years. Cancer of vulva is diagnosed in locally advanced stage in $59 \%$ of patients, in $29 \%$ in regionally advanced stage and in six percent in the stage of dissemination beyond the regionally advanced stage. The mean age of patients diagnosed with vulvar cancer is 69 years and death 78 years $[9,10]$. These values are comparable with the data of the International Federation of Gynaecology and Obstetrics [11] and the data from Australia [12].

The above differences between Polish and American data indicate that despite the same age of patients at the time of diagnosis with vulvar cancer, it occurs four times more often in the population of Polish women and five-year survival rates are recorded only in 54\% of Polish women [13-15] (only group treated with combined therapy) versus $71 \%$ of American women (the whole group). The comparison of the data suggests that vulvar neoplasms are diagnosed in more advanced clinical stages in Poland. Another explanation may be less effective treatment in 

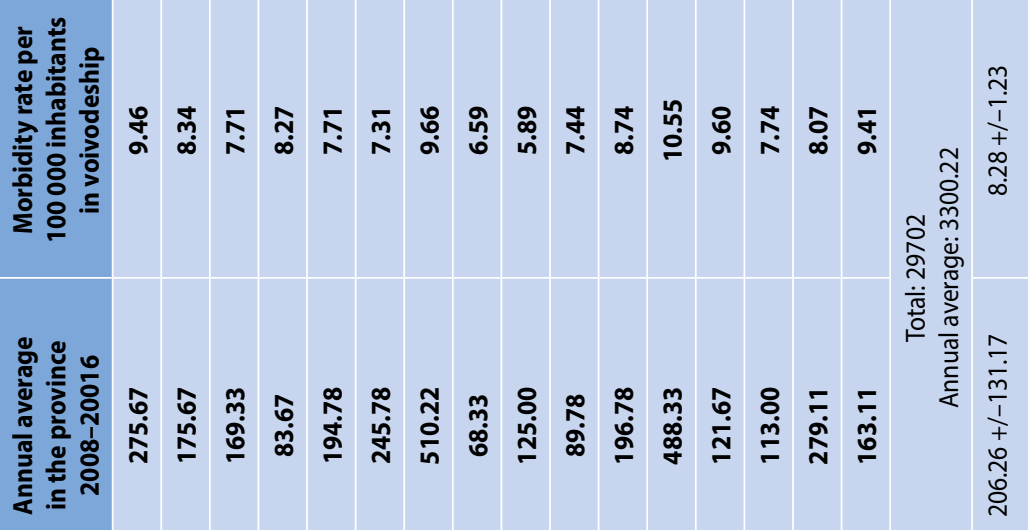

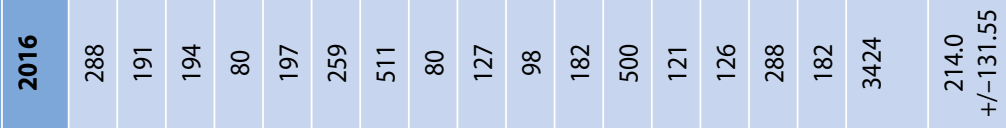

商

ปั่

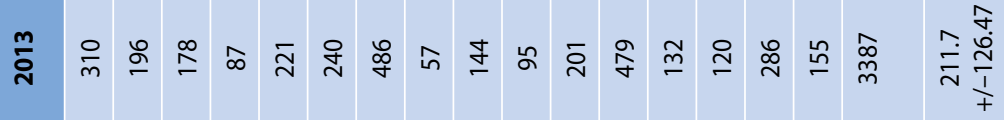
을

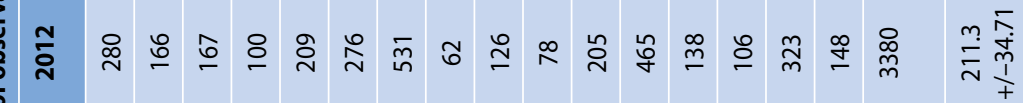
ขึ

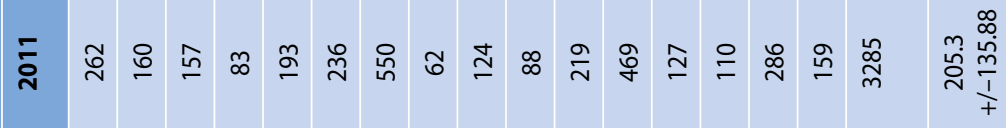

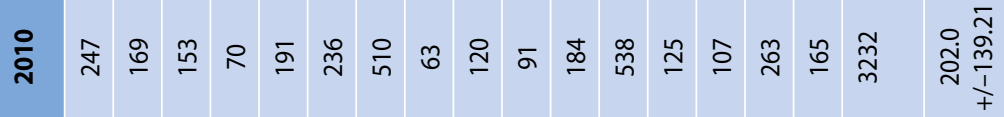

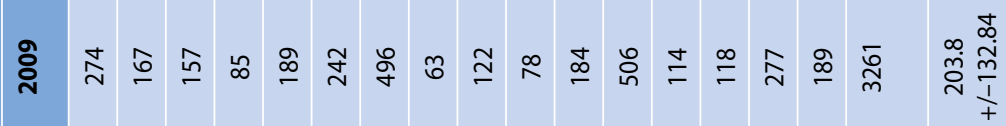

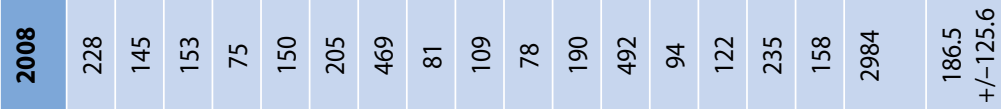




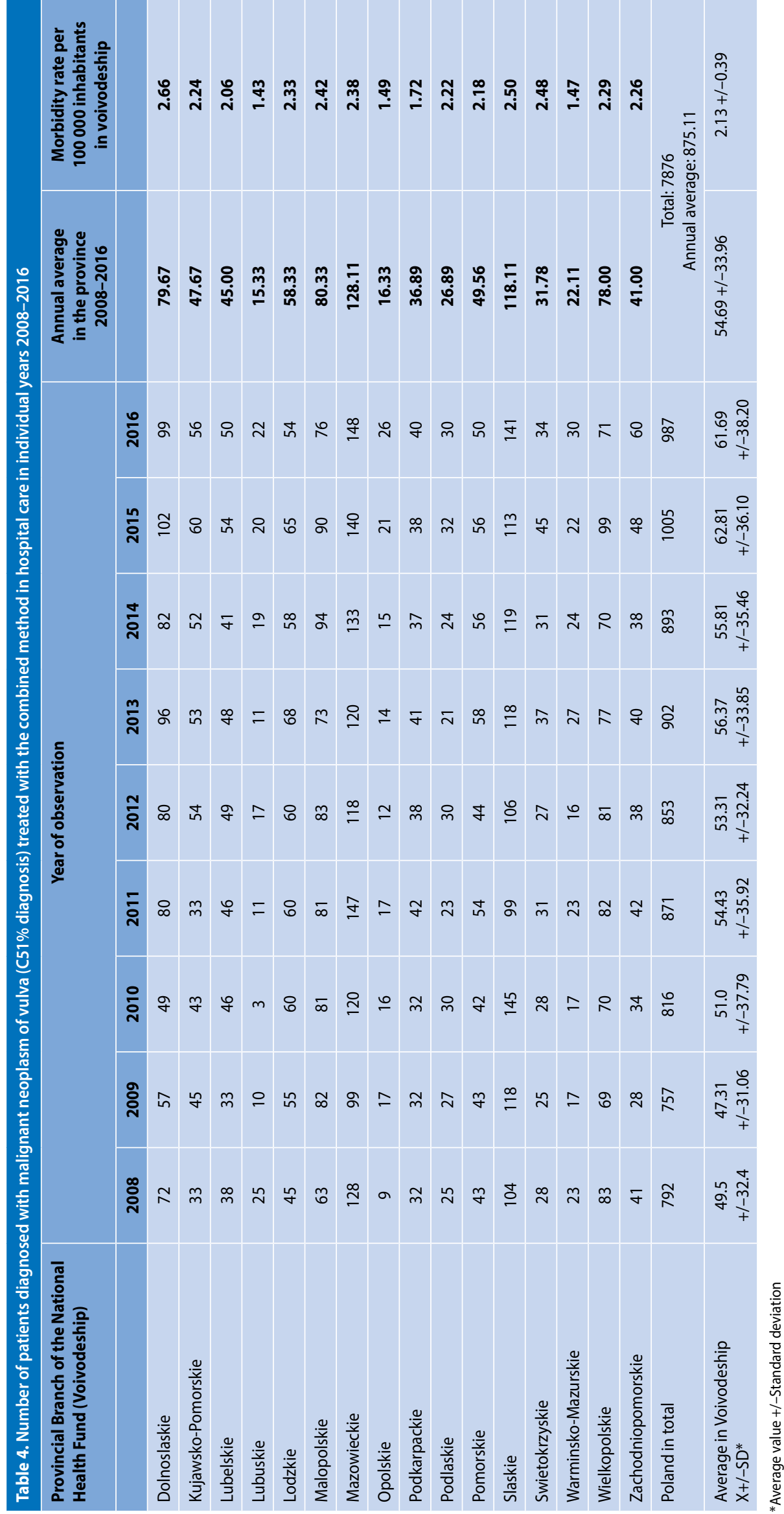




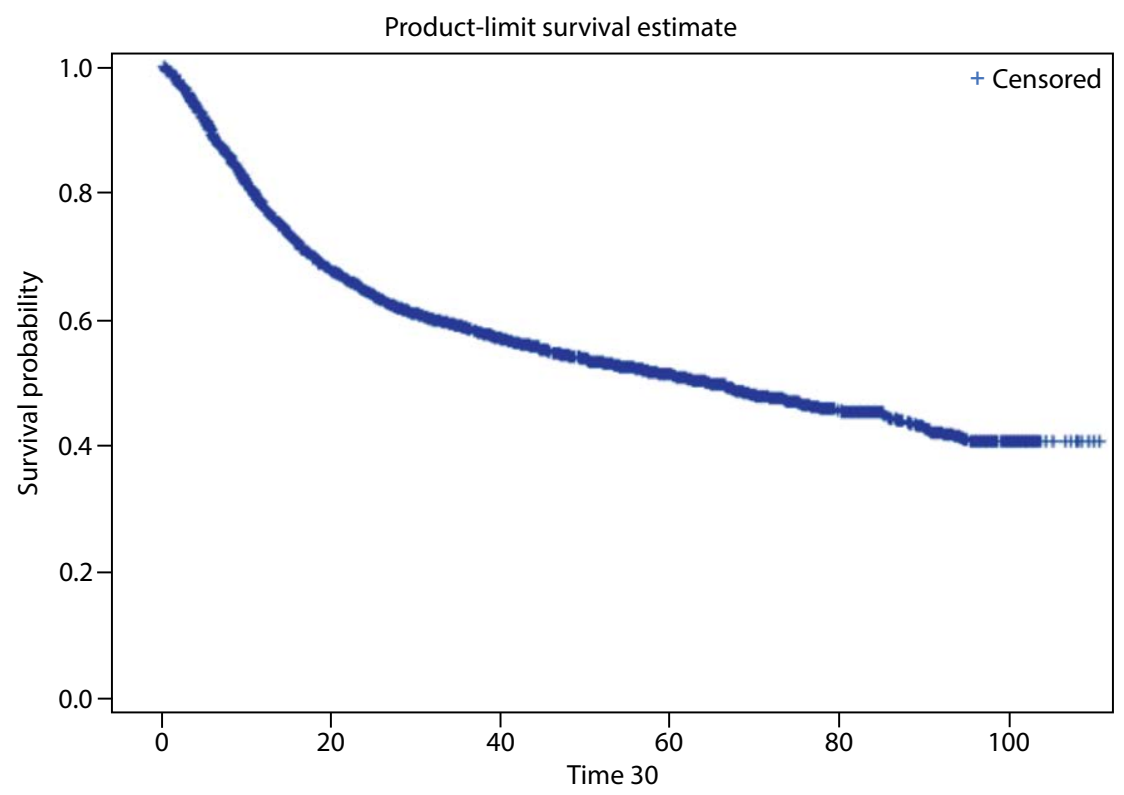

Figure 1. Kaplan-Meier estimation of overall survival in patients with malignant neoplasm of vulva (C51\% diagnosis)

this group of patients. Organizational problems mainly related to pathomorphological diagnostics may be an indirect cause of suboptimal therapies. The above presented data require further detailed analysis within the framework of the national statistics (Statistics Poland, Social Insurance Institution, National Health Fund, National Cancer Registry).

This study has several limitations. Firstly, our study is based on the data collected from the registry of the National Health Fund and the quality of reported data may influence the obtained results. Secondly, our analysis is limited to nine-year period and further analysis are needed to assess the epidemiology of vulvar cancer in Poland. However, our study also has practical implications. The incidence of vulvar cancer presented in this study and differences between data from the registry of the National Health Fund and other public institutions collecting data on cancer (including vulvar cancer) indicate an urgent need to verify the existing caner registers and introduce methods to improve the quality of collected data and ensure their comparability between institutions. In addition, data on the prevalence of vulvar cancer can be used to plan health policy programs at both the national and regional levels.

\section{CONCLUSIONS}

1. In the years 2008-2016 in Poland, based on the data reported to the National Health Fund, the incidence of vulvar cancer was four times higher than in the statistics of the National Cancer Registry, data from the WHO or the USA, which indicates either substantive or reporting errors.
2. Systemic treatment covered a greater percentage of patients in voivodships where oncology reference centres were located.

3. In Poland, $54 \%$ of patients treated with combined method survive over five years. Compared to highly developed countries, this result is unsatisfactory, in the USA this percentage is as high as $71 \%$.

4. Joint data from Statistics Poland, Social Insurance Institution, National Health Fund, National Cancer Registry and oncology registries are essential to develop standards of care and improved treatment outcomes for vulvar cancer patients.

\section{Conflict of interest}

All authors declare no conflict of interest.

\section{REFERENCES}

1. Kornafel J, Mądry R, Bidziński M. Rak sromu. In: Kornafel J, Mądry R. ed Nowotwory kobiecego układu płciowego. Wytyczne Polskiego Towarzystwa Onkologii Klinicznej, Warszawa 2013.

2. Minar $L$, Felsinger $M, C$ Cihalova $M$, et al. Vulvar cancer recurrence - an analysis of prognostic factors in tumour-free pathological margins patients group. Ginekol Pol. 2018; 89(8): 424-431, doi: 10.5603/GP.a2018.0073, indexed in Pubmed: 30215461.

3. Sznurkowski JJ, Milczek T, Emerich J. Prognostic factors and a value of 2009 FIGO staging system in vulvar cancer. Arch Gynecol Obstet. 2013; 287(6): 1211-1218, doi: 10.1007/s00404-012-2683-x, indexed in Pubmed: 23263173.

4. Wojciechowska U, Didkowska J. Zachorowania i zgony na nowotwory złośliwe w Polsce. Krajowy Rejestr Nowotworów, Narodowy Instytut Onkologii im. Marii Skłodowskiej-Curie - Państwowy Instytut Badawczy. http://onkologia.org.pl/nowotwory-sromu-pochwy-kobiet (2021.05.01).

5. World Health Organization. International Statistical Classification of Diseases and Related Health Problems(ICD-10). http://stat.gov.pl/Klasyfikacje/doc/icd10/pdf/ICD10Toml.pdf (2021.05.01). 
6. Government of Poland. PESEL. https://obywatel.gov.pl/pl/dokumenty-i-dane-osobowe/czym-jest-numer-pesel (2021.05.01).

7. Journal of Laws. Ustawa z dnia 27.08.2008 roku o Świadczeniach Opieki Zdrowotnej finansowanych ze środków publicznych (Dz. U. 2008. nr 164 poz. 1027 z późn. zm). http://isap.sejm.gov.pl/isap.nsf/DocDetails. xsp?id=WDU20042102135 (2021.05.01).

8. Fendler W, Chałubińska J, MłynarskiW. ethods of survival analysis applied in oncology - assumptions, methods and common pitfalls. Onkol Prak Klin. 2011; 7(2): 89-101.

9. National Cancer Institute (US). Cancer Stat Facts: Vulvar Cancer. https:// seer.cancer.gov/statfacts/html/vulva.html (2021.05.01).

10. Siegel RL, Miller KD, Jemal A. Cancer Statistics, 2017. CA Cancer J Clin. 2017; 67(1): 7-30, doi: 10.3322/caac.21387, indexed in Pubmed: 28055103.

11. Woelber $L$, Trillsch F, Kock $L$, et al. Management of patients with vulvar cancer: a perspective review according to tumour stage. Ther Adv Med
Oncol. 2013; 5(3): 183-192, doi: 10.1177/1758834012471699, indexed in Pubmed: 23634196.

12. Barlow EL, Kang YJ, Hacker NF, et al. Changing trends in vulvar cancer incidence and mortality rates in Australia since 1982. Int J Gynecol Cancer. 2015; 25(9): 1683-1689, doi: 10.1097/IGC.0000000000000547, indexed in Pubmed: 26495761.

13. Banas T, Pitynski $K$, Jach $R$, et al. Primary vulvo-vaginal cancers: trends in incidence and mortality in Poland (1999-2012). Gynecol Obstet Invest. 2015; 80(4): 240-245, doi: 10.1159/000381770, indexed in Pubmed: 26065364.

14. Perzyło K, Miotła $P$, Lis $E$, et al. Therapeutic and prognostic value of lymphadenectomy in gynecological oncology. Ginekol Pol. 2013; 84(7): 630-636, doi: 10.17772/gp/1616, indexed in Pubmed: 24032276.

15. Gaudineau A, Weitbruch D, Quetin P, et al. Neoadjuvant chemoradiotherapy followed by surgery in locally advanced squamous cell carcinoma of the vulva. Oncol Lett. 2012; 4(4): 719-722, doi: 10.3892/ol.2012.831, indexed in Pubmed: 23205089. 